\title{
EFEKTIFITAS PENERAPAN OUTBOUND TRAINING DALAM MENINGKATKAN KEMAMPUAN RESOLUSI KONFLIK INTERPERSONAL PADA REMAJA
}

\author{
Hetti Sari Ramadhani dan Diana Rahmasari \\ Program Studi Psikologi Universitas Negeri Surabaya \\ e-mail: direnavi@yahoo.com
}

\begin{abstract}
Abstrak: Penelitian ini bertujuan untuk menguji keefektifan outbound training dalam meningkatkan kemampuan resolusi konflik interpersonal pada remaja. Subjek penelitian adalah peserta remaja outbound training dengan rentang usia 16-19 tahun The Survival Outbound Team Prigen Pasuruan. Penelitian ini menggunakan true experiment yaitu kelompok eksperimen adalah 10 remaja yang terdaftar sebagai peserta outbound training dan kelompok kontrol adalah 10 remaja yang tidak terdaftar sebagai peserta outbound training. Pengambilan subjek penelitian menggunakan teknik purposive sampling yakni mereka yang memiliki skor resolusi konflik interpersonal rendah. Pengumpulan data menggunakan angket resolusi konflik interpersonal yang dinyatakan dalam bentuk ordinal dan menggunakan statistik parametrik dengan paired sampel t test dan independent t test. Hasil analisis data diperoleh nilai t sebesar 9,635 dan $\mathrm{p}=0,000(\mathrm{p}<0,025)$ sehingga hipotesis penelitian diterima. Artinya, ada perbedaan yang signifikan terhadap skor resolusi konflik interpersonal remaja antara sebelum dan sesudah diberikan outbound training pada taraf $\alpha=0,05 \%$. Diperoleh nilai t sebesar 5,069 dan $\mathrm{p}=0,000$ $(p<0,025)$ sehingga hipotesis penelitian diterima. Artinya, ada perbedaan yang signifikan terhadap skor resolusi konflik interpersonal antara remaja yang mendapat outbound training dan remaja yang tidak mendapat outbound training pada taraf $\alpha=0,05 \%$. Dari data analisis, dapat disimpulkan bahwa penerapan outbound training efektif dalam meningkatkan kemampuan resolusi konflik interpersonal remaja.
\end{abstract}

Kata kunci: outbound training, resolusi konflik interpersonal.

\begin{abstract}
This study aims to test the effectiveness of outbound training in improving interpersonal conflict resolution skills in adolescents. Subjects were adolescents outbound training participants with age ranges between 16-19 years old on the Team Survival Outbound Prigen Pasuruan. The design of this study was a true experiment, with 10 participants who were registered as outbound training participant was being assigned as experiment group and 10 participants who were not registered as outbound training participant was being assigned to control group Sampling technique used in this research was purposive sampling by selecting participants with low conflict resolution score. Data collecting method used was interpersonal conflict resolution questionnaire which resulting in an ordinal scale and was analysed using parametric statistic with t-test paired sample and independent t-test. Obtained score was $t=9.635$ and $p=0.000(p<0.025)$, which means that the research hypothesis was accepted. In other words, there were a significant difference between adolescence interpersonal conflict resolution score prior-and post-intervention (outbound training) in $\alpha=0.05 \%$. Obtained score was $t=5.069$ and $p=0.000(p<0.025)$, which means that the research hypothesis was accepted. It can be concluded, that there were a significant difference between adolescence interpersonal conflict resolution score priorand post-intervention (outbound training) in $\alpha=0.05 \%$. Based on those results, it can be concluded that an effective implementation of outbound training can increase interpersonal conflict resolution skill in adolescence.
\end{abstract}

Key words: outbound training, interpersonal conflict resolution

Dunia pendidikan mulai marak dengan kekerasan, dimana fenomena tersebut sering terjadi baik antar siswa maupun guru dengan siswa. Kekerasan ini bahkan sudah terlihat sejak anak berada di bangku pendidikan awal yang justru terbawa sampai seterusnya. Konflik dan kekerasan di sekolah tampak melalui adanya sikap intimidasi, ancaman, perampokan, vandalisme, serangan fisik, godaan seksual, pemerkosaan, hingga pembunuhan (Esther dkk, 2005). Bentuk kekerasan di sekolah juga dapat berupa hukuman fisik, pemerasan, gertakan, perkelahian dan bentuk verbal yang akibatnya 
membuat anak takut untuk pergi ke ruang istirahat, takut keluar halaman sekolah, prestasi belajar menurun, terganggu jam pelajaran dan membuat orang tua khawatir terhadap keselamatan anaknya (Elliot dkk., 1998).

Perkembangan emosi yang belum stabil cenderung membuat remaja mudah marah dan bergejolak. Kondisi remaja sebagai proses peralihan perkembangan membuat mereka rentan dengan konflik interpersonal. Menurut Walgito (2007), konflik interpersonal adalah suatu situasi dimana dua orang atau lebih atau dua kelompok atau lebih tidak setuju terhadap hal-hal atau situasi-situasi yang berkaitan dengan keadaan-keadaan yang antagonistis. Pertentangan kepentingan diantara anggota kelompok atau komunitas masyarakat merupakan suatu kewajaran. Dalam kehidupan yang dinamis antar individu dan antar komunitas baik dalam organisasi maupun di masyarakat yang majemuk, konflik selalu terjadi manakala saling berbenturan kepentingan.

Wahyudi (2008) menambahkan bahwa pengertian konflik interpersonal adalah perselisihan, pertentangan antara dua orang/dua kelompok dimana perbuatan yang satu berlawanan dengan yang lainnya, sehingga salah satu atau keduanya saling terganggu. Adanya konflik menunjukkan ciriciri sebagai berikut. Pertama, terdapat perbedaan pendapat atau pertentangan antar individu atau kelompok. Kedua, terdapat perselisihan dalam mencapai tujuan yang disebabkan adanya perbedaan persepsi dalam menafsirkan sesuatu. Ketiga, terdapat pertentangan norma, dan nilai-nilai individu maupun kelompok. Keempat, adanya sikap dan perilaku saling meniadakan, menghalangi pihak lain untuk memperoleh kemenangan dalam memperebutkan sumber daya yang terbatas, dan kelima, adanya perdebatan dan pertentangan sebagai akibat munculnya kreatifitas, inisiatif, atau gagasan-gagasan baru.

Konflik yang ada dalam diri remaja sangat perlu untuk dikelola dengan baik karena dampak konflik yang tidak terselesai- kan akan muncul dalam kegelisahan dan kecemasan yang akan mewarnai sikap dan tingkah lakunya. Ia menjadi mudah sekali marah, tersinggung, kecewa dan putus asa. Remaja yang tidak dapat menyelesaikan konflik dalam diri mereka sendiri bisa jadi terbawa ke dalam konflik yang jauh lebih besar yang dapat mengantarkan mereka pada kenakalan remaja (juvenile delinquency). State Of Our Nation's Youth (2000) telah menemukan bahwa $40 \%$ siswa remaja cenderung melakukan tindak kekerasan dan $20 \%$ siswa remaja terlibat dalam kekerasan fisik (Sciarra, 2004). Demikian halnya National Center for Education Statistics (NCES) menemukan kekerasan pada siswa SD dan SMP pada tahun 1996/1997 telah mengalami peningkatan sekitar $57 \%$ (Esther dkk., 2005).

Pentingnya bagi remaja untuk dibekali kecakapan resolusi konflik interpersonal adalah karena remaja merupakan pewaris tata kehidupan masyarakat. Dalam menghadapi situasi konflik adalah mengendalikan atau mengatur konflik agar konflik tidak terwujud dalam bentuk kekerasan, sehingga pemahaman terhadap resolusi konflik disini diarahkan pada konteks pengaturan atau pengendalian konflik (Noor, 2001). Menurut Deutsch (2000) hal penting bukanlah konflik itu baik atau buruk, melainkan bagaimana remaja bisa menangani konflik sehingga menjadi konstruktif. Remaja dengan konflik yang tidak terselesaikan akan berdampak dalam gangguan psikis, fisik dan perilaku. Gangguan psikis berupa sulit berkonsentrasi, kurang dapat berpikir jernih dan mudah marah, gangguan fisik berupa rasa pusing dan sulit tidur, serta gangguan perilaku berupa mengasingkan diri dari pergaulan, sulit mengadakan hubungan dengan orang lain, dan dapat pula berperilaku agresif(Walgito, 2007).

Menurut Weitzman \& Patricia (2000) konflik tidak selamanya bermakna distruktif tetapi juga bisa dikelola untuk menjadi konstruktif. Konstruktif tidaknya suatu konflik tergantung pada pemahaman, 
keterampilan dan kompetensi seseorang dalam melakukan resolusi konflik baik intramaupun inter-personal. Upaya penanganan konflik yang bersifat dinamis dan fleksibel dengan pola resolusi konflik yaitu melalui cara-cara pengaturan atau pengendalian dengan memanfaatkan secara aktif bentukbentuk komunikasi untuk menekan konflik itu sendiri. Jika individu memiliki persepsi negatif atas konflik yang terjadi, maka sikap dan tingkah laku pemecahan konflik cenderung destruktif-disfungsional. Sebaliknya cara pandang positif melahirkan persepsi, sikap, respon tingkah laku solusi konflik konstruktif-fungsional.

Resolusi konflik yang konstruktif akan membawa beberapa manfaat dalam diri seseorang dan berdampak positif antara lain: meningkatkan harga diri, kepercayaan yang lebih besar, meningkatkan harga diri dalam kelompok serta meningkatkan hubungan lebih erat dalam kelompok (Walgito, 2007). Selain itu, dengan terbentuknya resolusi konflik mereka dapat menemukan cara yang baik memecahkan kontroversi dengan orang lain, menemukan ide-ide kreatif, belajar untuk mendengarkan, bersikap dan menyamakan perbedaan tersebut (Somech, 2008).

Salah satu media alternatif memunculkan beberapa aspek resolusi konflik pada remaja adalah melalui media experiental learning dimana remaja akan dituntut berpikir kreatif dan menyelesaikan suatu permasalahan tertentu dengan berkelompok secara langsung. Materi pelatihan di alam terbuka atau yang lebih dikenal dengan Outbound Training telah merambah ke dunia pendidikan dan membantu permasalahan dalam pendidikan.

Menurut Ancok (2002) Outbound training adalah suatu program pelatihan di alam terbuka yang mendasarkan pada prinsip "experiental learning" belajar melalui pengalaman langsung yang disajikan dalam bentuk permainan, diskusi, simulasi, dan petualangan sebagai media penyampaian materi.
Penjelasan tersebut juga mendapat dukungan yang lebih jelas dalam menggambarkan kegiatan outbound training di lapangan yaitu menurut Asti (2009), Outbound training adalah kegiatan pelatihan di luar ruangan atau di alam terbuka yang menyenangkan dan penuh tantangan dengan bentuk kegiatan berupa simulasi kehidupan melalui permainan yang kreatif, rekreatif dan edukatif baik secara individual maupun kelompok dengan tujuan untuk pengembang-an diri (personal deveopment) maupun kelompok (team development). Kayes (2005) menambahkan dalam jurnalnya bahwa outbound training merupakan: "a structure way to help team develop the essential competencies necessary for team learning". Berdasarkan definisi tersebut di atas maka dapat disimpulkan bahwa outbound training merupakan suatu metode pelatihan di alam terbuka yang dilakukan untuk meningkatkan kompetensi diri dan manajemen diri yang baik.

Outbound training merupakan media experiental learning, sehingga tepat jika digunakan dalam pengembangan resolusi konflik interpersonal. Karakteristik outbound dengan fun games lebih banyak digunakan karena menyenangkan dan tidak membosankan terutama untuk fase remaja yang dinamis. Kenyataanya bahwa seseorang memulai proses pendidikan awal dengan bermain dan having fun di usia anak-anak. Permainan adalah budaya lama. Dan pada perkembangannya permainan memiliki fungsi yang signifikan dalam perkembangan budaya dan terlebih pada fenomena-fenomena psikologis atau refleksi psikologis (Wheatley, 1999).

Outbound Training dapat membantu seseorang untuk meningkatkan kemampuan resolusi konflik interpersonal. Outbound Training dinilai mampu memberi kontribusi positif pada pribadi seseorang dan efektif dalam membangun pemahaman terhadap suatu konsep dan membangun perilaku baru yang konstruktif (Asti, 2009). Ada berbagai alasan mengapa metode outbound efektif dalam membangun pemahaman terhadap 
suatu konsep dan membangun perilaku, antara lain : metode outbound adalah simulasi kehidupan yang kompleks dengan permasalahan yang dibuat menjadi sederhana, metode ini memakai experiental learning dan metode ini penuh kegembiraan karena dilakukan dengan permainan (Ancok: 2002).

Oleh karena itu dengan karakteristik remaja yang enerjik, Outbound Training bisa menjadi suatu cara baru yang menyenangkan untuk membantu remaja meningkatkan kemampuan resolusi konflik interpersonal yang dapat bermanfaat untuk berhasil menghadapi setiap permasalahan yang mereka temui.

Berdasarkan hal tersebut diatas, peneliti tertarik untuk membuat suatu penelitian eksperimen untuk mengetahui adanya efektifitas Outbound Training pada peningkatan kemampuan resolusi konflik interpersonal, sehingga penelitian ini berjudul outbound training".

Berdasarkan rumusan masalah, maka tujuan penelitian ini adalah memperoleh data guna menguji keefektifan penerapan Outbound Training dalam meningkatkan kemampuan resolusi konflik interpersonal remaja.

\section{METODE}

Metode yang digunakan dalam penelitian ini adalah penelitian eksperimen dengan cara memberikan perlakuan outbound training pada kelompok eksperimen dan kelompok kontrol tanpa diberikan outbound training. Dalam desain ini subjek dikenakan perlakuan dengan dua kali pengukuran. Pengukuran yang pertama dilakukan sebelum pemberian outbound training dan pengukuran kedua dilakukan setelah pemberian outbound training kepada subjek penelitian. Desain tersebut dapat digambarkan sebagai berikut.

\section{Bagan. 1 Desain Penelitian}

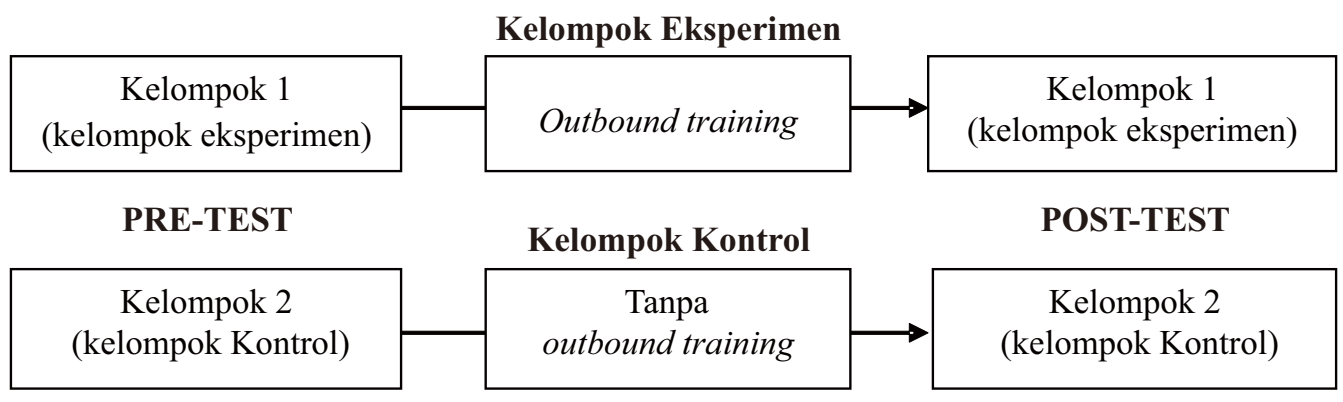

"Efektifitas Penerapan Outbound Training dalam Meningkatkan Kemampuan Resolusi konflik Interpersonal pada Remaja".

Dari latar belakang yang telah dipaparkan di atas, maka masalah dalam penelitian ini dirumuskan sebagai berikut. Secara umum, apakah penerapan Outbound Training efektif dalam meningkatkan kemampuan resolusi konflik interpersonal pada remaja? Secara lebih operasional, adakah peningkatan skor kemampuan resolusi konflik interpersonal sebelum dan sesudah penerapan outbound training? Adapun hipotesis pada penelitian ini adalah: "Terdapat perbedaan nilai test ratarata antara sebelum dan sesudah mengikuti

\section{Subjek Penelitian}

Subjek dalam pelaksanaan penelitian ini atau yang bertindak sebagai populasinya adalah seluruh remaja peserta outbound training di Pusat Pelatihan Outbound "The Survival Outbound Team" Prigen Pasuruan. Peserta outbound training adalah remaja dengan usia antara 16-19 tahun sejumlah 55 orang. Penentuan subjek ini menggunakan sampling bertujuan (purposive sampling), yaitu teknik sampling yang digunakan oleh peneliti jika peneliti mempunyai pertimbangan-pertimbangan tertentu di dalam pengambilan sampelnya. Pengambilan 
sampel diambil dari siswa yang memiliki skor resolusi konflik interpersonal paling rendah. Peneliti mengambil sampel kelompok eksperimen sejumlah 10 remaja yang memiliki nilai terendah dan untuk kelompok kontrol peneliti mengambil 10 remaja yang memiliki nilai terendah yang tidak mengikuti outbound. Peneliti mengambil kelompok kontrol dari siswa SMAN 3 Surabaya usia 1619 tahun yang tidak mengikuti outbound

\section{Teknik pengumpulan data}

Pengumpulan data menggunakan angket resolusi konflik interpersonal menggunakan skala Likert. Pembuatan angket didasarkan pada Aspek-aspek Resolusi Konflik Interpersonal. Skala ini berisikan seperangkat pernyataan yang merupakan memperlihatkan pendapat yang positif (favorable) maupun negatif (unfavorable). Dalam penskalaan model Likert dikenal lima alternatif jawaban atas pernyataan yang ada yakni Sangat Sering (SS), Sering (S), KadangKadang (K), Pernah (P), dan Tidak Pernah (TP). Pengujian validitas instrumen dalam penelitian ini adalah dengan cara analisis butir dengan asumsi bahwa instrumen itu dikatakan valid jika setiap butir soal instrumen tersebut valid. Pengujian validitas dilakukan dengan menggunakan rumus korelasi product moment dari Pearson. Pengukuran validitas instrumen diperoleh dari hasil uji instrumen terhadap 40 responden remaja.

Pengujian validitas di lakukan dengan menggunakan korelasi product moment dari Pearson dengan menggunakan SPSS versi 17,0 for windows. Hasil setiap butir soal dianggap valid jika memenuhi kriteria penggunaan rumus, yaitu apabila $\mathrm{r}_{\text {hitung }}>\mathrm{r}_{\text {tabel, }}$ dengan taraf kepercayaan 95\% $(0,05)$. Sebaliknya, jika $\mathrm{r}_{\text {hitung }}<\mathrm{r}_{\text {tabel }}$, maka instrumen tersebut dinyatakan tidak valid. Butir instrumen dikatakan valid jika $r_{\text {hitung }}>0,300$. Item-item instrumen yang dinyatakan valid berarti sudah memadai untuk digunakan dalam melakukan penelitian. Berdasarkan uji validitas maka terdapat 38 butir yang valid dan 12 butir yang gugur dari 50 butir aitem yang dibuat (seperti yang ada dalam lampiran 3.2). Butir gugur terdapat pada semua indikator, namun tiap-tiap indikator tetap terwakili oleh butir yang valid. Koefisien korelasi untuk butir-butir yang valid bergerak dari 0,315 sampai 0,670.

Pada penelitian ini cara yang digunakan untuk mengukur reliabilitas adalah menggunakan rumus alpha cronbach pada skala Resolusi Konflik Interpersonal. Penghitungan reliabilitas dalam penelitian ini juga menggunakan bantuan program SPSS 17,0 for windows. Hasil uji reliabilitas menunjukkan koefisien reliabilitas sebesar 0,906, yang mana nilai cronbach's alpha dengan $\alpha=0,906>0,6$ dan dengan $\mathrm{p}=0,000$ $(\mathrm{p}<0,001)$ maka kuesioner Resolusi Konflik Interpersonal dinyatakan sangat reliabel. Artinya, alat ukur Resolusi Konflik Interpersonal menunjukkan kestabilan dan memiliki konsistensi atau keajegan.

\section{Teknik Analisis Data}

Variabel bebas adalah variabel yang mempengaruhi variabel lain. Variabel bebas dalam penelitian ini adalah Outbound training. Varibel terikat adalah variabel yang dipengaruhi karena adanya variabel bebas. Variabel terikat dalam penelitian ini adalah kemampuan resolusi konflik interpersonal. Data pada penelitian ini merupakan data ordinal dan menggunakan statistik parametrik untuk mengetahui efektivitas outbound training dalam meningkatkan kemampuan resolusi konflik interpersonal. Penghitungan ini menggunakan uji $\mathrm{t}$ dengan dua sampel berpasangan (Paired sample t test) dan uji t dengan dua sampel bebas (independent $t$ test) yang nantinya dilakukan dengan menggunakan bantuan program SPSS 17,0 for windows. Pengujian hipotesis ini dengan menggunakan uji beda rata - rata berpasangan atau disebut paired sample t test. Pengujian ini bertujuan untuk menguji signifikansi dari 
perbedaan antara sampel atau variabel yang sama dengan dua perlakuan yang berbeda. Artinya apakah dengan perlakuan yang berbeda terhadap sebuah sampel akan berbeda secara statistik atau tidak.

\section{HASIL DAN PEMBAHASAN}

\section{Hasil}

Berikut deskripsi data hasil penelitian berdasarkan Selisih Nilai (Gain Score) dari kelompok kontrol dan kelompok eksperimen. angket resolusi konflik interpersonal dimana diperoleh dari hasil pengurangan antara post-test dengan pre-test sedangkan sebanyak 1 remaja atau sebesar $10 \%$ tidak mengalami perubahan dari hasil post-test dan pre-testnya dan yang terakhir terdapat 5 remaja atau 50\% meng alami selisih angka naik akan tetapi selisih angka kenaikan itu tidak besar yaitu hanya berada di kisaran 3 sampai -1. Dan dari hasil uji pre-test dengan post-test dapat diperoleh deskripsi statistik kelompok kontrol di tabel 2 sebagaiberikut:

Tabel 1. Hasil Pre-test dan Post-test dua kelompok dengan Gain Score

\begin{tabular}{|c|c|c|c|c|c|c|}
\hline \multirow{2}{*}{ NO } & \multicolumn{3}{|c|}{ Kelompok Kontrol } & \multicolumn{2}{c|}{ Kelompok Eksperimen } \\
\cline { 2 - 7 } & $\begin{array}{c}\text { Hasil } \\
\text { Pre-test }\end{array}$ & $\begin{array}{c}\text { Hasil } \\
\text { Post-test }\end{array}$ & $\begin{array}{c}\text { Gain } \\
\text { Score }\end{array}$ & $\begin{array}{c}\text { Hasil } \\
\text { Pre-test }\end{array}$ & $\begin{array}{c}\text { Hasil } \\
\text { Post-test }\end{array}$ & $\begin{array}{c}\text { Gain } \\
\text { Score }\end{array}$ \\
\hline 1. & 133 & 136 & +3 & 144 & 165 & +23 \\
\hline 2. & 130 & 132 & +2 & 142 & 163 & +19 \\
\hline 3. & 124 & 123 & -1 & 121 & 153 & +32 \\
\hline 4. & 122 & 122 & 0 & 119 & 145 & +26 \\
\hline 5. & 95 & 98 & +3 & 103 & 144 & +41 \\
\hline 6. & 105 & 107 & +2 & 105 & 139 & +34 \\
\hline 7. & 142 & 144 & +2 & 142 & 169 & +27 \\
\hline 8. & 136 & 135 & -1 & 135 & 170 & +35 \\
\hline 9. & 145 & 144 & -1 & 138 & 155 & +17 \\
\hline 10. & 127 & 126 & -1 & 123 & 172 & +49 \\
\hline $\mathbf{\Sigma}$ & 1259 & 1267 & 5 & 1272 & 1575 & 303 \\
\hline $\bar{X}$ & 125,9 & 126,7 & 0,5 & 127,2 & 157,5 & 30,3 \\
\hline
\end{tabular}

Tabel 2. Deskripsi Statistik Kelompok Kontrol

\begin{tabular}{|c|c|c|c|c|c|c|c|c|}
\hline \multicolumn{2}{|c|}{ KELOMPOK } & N & Mean & SD & Range & Max. & Min. & Varian \\
\hline \multirow{2}{*}{ Kontrol } & pre-test & 10 & 125,90 & 15,652 & 50 & 145 & 95 & 244,989 \\
& post test & 10 & 126,70 & 15,018 & 46 & 144 & 98 & 225,567 \\
\hline
\end{tabular}

Perbandingan rata-rata nilai gain score kelompok kontrol dan kelompok eksperimen menunjukkan bahwa kelompok eksperimen lebih unggul 29,8. Hasil ini menunjukkan bahwa metode outbound training dapat meningkatkan skor resolusi konflik interpersonal.

Dari hasil diatas dapat dijelaskan bahwa sebanyak 4 remaja atau sebesar $40 \%$ terdapat selisih angka yang menurun dari
Dari data tabel 2 terlihat selisih peningkatan rata-rata mean pada saat pre-test dan post-test hanya 0,80 .

\section{Kelompok Eksperimen}

Kelompok eksperimen menunjukkan bahwa 10 remaja atau $100 \%$ mengalami kenaikan penuh dan selisih angka naik berkisar antara 19-49. Berikut deskripsi data 
kelompok eksperimen dalam tabel 3 sebagai berikut: artinya Ada perbedaan nilai test rata-rata antara sebelum dan sesudah mengikuti

Tabel 3. Deskripsi Statistik Kelompok Eksperimen

\begin{tabular}{|c|c|c|c|c|c|c|c|c|}
\hline \multicolumn{2}{|c|}{ KELOMPOK } & N & Mean & SD & Range & Max. & Min. & Varian \\
\hline \multirow{2}{*}{ eksperimen } & pre-test & 10 & 127,20 & 15,273 & 41 & 144 & 103 & 233,289 \\
& post-test & 10 & 157,50 & 11,983 & 33 & 172 & 139 & 143,611 \\
\hline
\end{tabular}

Dari data tabel 3 terlihat selisih peningkatan rata-rata mean pada saat pre-test dan post-test adalah 30,3, sehingga terlihat ada peningkatan yang besar.

Pengujian hipotesis tersebut dilakukan dengan uji-t dengan taraf signifikansi 0,05 pada tabel 4 sebagai berikut : outbound training. Perbedaan tersebut menunjukkan bahwa outbound training sangat berpengaruh untuk meningkatkan skor post-test. Sedangkan untuk besarnya pengaruh tersebut ditunjukkan dengan koefisien atau uji signifikan diperoleh sebesar 0,954 yang menandakan bahwa outbound

Tabel 4. Statistik paired samples $\mathrm{t}$ tests

\begin{tabular}{|c|c|c|c|c|c|}
\hline \multicolumn{2}{|c|}{ KELOMPOK } & $\mathbf{N}$ & Mean & Std. deviation & Std. error mean \\
\hline \multirow{2}{*}{ Eksperimen } & pre-test & 10 & 127.200 & 15.27380 & 4.83000 \\
& post-test & 10 & 157.500 & 11.98379 & 3.78961 \\
\hline \multirow{2}{*}{ Kontrol } & pre-test & 10 & 125.900 & 15.65212 & 4.94964 \\
& post-test & 10 & 126.700 & 15.01888 & 4.74939 \\
\hline
\end{tabular}

Tabel 5. Korelasi paired samples t tests

\begin{tabular}{|c|c|c|c|c|}
\hline \multicolumn{2}{|c|}{ KELOMPOK } & $\mathbf{N}$ & Korelasi & Sig. \\
\hline Eksperimen & pre-test post-test & 10 & 0,759 & .011 \\
\hline Kontrol & pre-test post-test & 10 & 0,994 & .000 \\
\hline
\end{tabular}

Tabel 6. Tes paired samples t tests

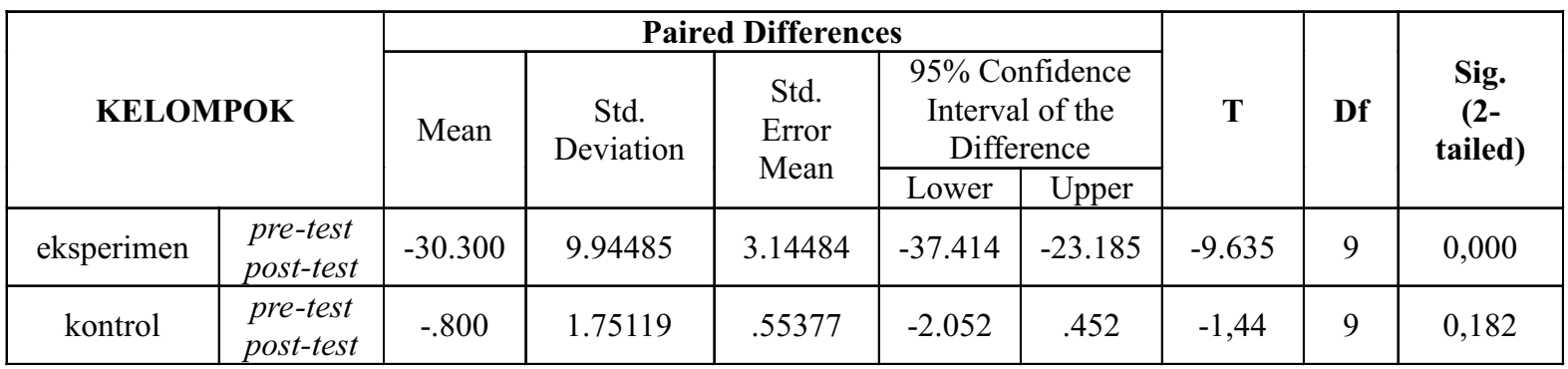

Dari perhitungan di atas kelompok eksperimen memperoleh nilai $\operatorname{Sig}$ (2-tailed) $(0,000)<1 / 2 \alpha \dot{\alpha}(0,025)$, maka Ho ditolak dan $\mathrm{H}_{1}$ diterima sehingga dalam penghitungan ini menunjukkan ada perbedaan nilai rata-rata test sebelum dan sesudah mengikuti outbound training. Atau dapat dilihat pula dari nilai $\mathrm{t}$ hitung sebesar -9.635 yang dimutlakkan menjadi 9,635 kemudian dibandingkan dengan nilai $t$ tabel sebesar 0,703 sehingga diperoleh $\mathrm{t}$ hitung $(9,635)>\mathrm{t}$ tabel $(0,703)$ dan dapat dikatakan Ho ditolak dan $\mathrm{H}_{1}$ diterima, training mempunyai pengaruh yang kuat terhadap peningkatan kemampuan resolusi konflik interpersonal remaja.

\section{Pembahasan}

Konsep dari resolusi konflik menurut Hugh Miall, Oliver Ramsbothan dan Tom Woodhouse (1999) adalah mengupayakan penanganan konflik yang bersifat dinamis dan fleksibel melalui cara-cara pengaturan atau pengendalian dengan memanfaatkan secara 
aktif bentuk-bentuk komunikasi untuk menekan konflik itu sendiri melalui sikap:Mendengarkan secara aktif dan reflektif pihak lain; memperhatikan dan memfokuskan pada apa yang dikatakan pihak lain serta mengkomunikasikan kembali apa yang telah dimengerti, Melatih dan menumbuhkan empati; mendengarkan secara aktif dalam menyalami perasaan pihak lain sehingga dapat ikut merasakan apa yang dirasakan pihak lain, Menerima, memberi dan menggunakan masukan yang konstruktif; dengan mendengarkan dan menyelami apa yang dikemukakan pihak lain, kita dapat memahami perilaku yang positif dan negatif beserta dampaknya, baik pada diri seseorang maupun kelompok atau dua-duanya dan berani melakukan kontak langsung, masingmasing pihak dapat menyelami apa yang ada sebenarnya pada masing-masing pihak. Sehingga remaja dengan Resolusi konflik interpersonal baik akan mampu menciptakan konflik yang konstruktif dan akan membawa beberapa manfaat dalam diri remaja tersebut.

Outbound training memiliki simulasi kehidupan yang kompleks dengan permasalahan yang dibuat dengan sederhana. Dan pada perkembangannya permainan memiliki fungsi yang signifikan dalam fenomenafenomena psikologis atau refleksi psikologis (Wheatley, 1999). outbound training adalah metode experiental learning yang efektif untuk membangun pemahaman suatu konsep dan membangun perilaku baru dalam diri seseorang (Ancok, 2002). Metode experiental learning merupakan cara yang tepat untuk membentuk perilaku-perilaku baru yang konstruktif dalam diri remaja. outbound training efektif dalam membangun kemampuan dalam resolusi konflik interpersonal.

Outbound training yang dimaksud terdiri dari games Pindah Ranjau, Bola Pimpong Bertali, Titanic dan Step by Step. Dengan perlakuan outbound training ini diharapkan dapat meningkatkan kemampuan resolusi konflik interpersonal remaja.

Pada penelitian ini outbound training banyak membantu remaja dalam mengembangkan kemampuan resolusi konflik interpersonal untuk menyelesaikan konflik yang mutlak ada dalam kehidupan mereka. Dalam uji hipotesis paired t test menunjukkan hasil penerimaan $\mathrm{H}_{1}$ dimana Ada perbedaan yang signifikan antara sebelum dan sesudah mengikuti outbound training dengan uji keberartian yang "sangat kuat". Sedangkan dalam uji independent $t$ test menunjukkan bahwa rata-rata kelompok kontrol dan kelompok eksperimen berbeda sehingga diperoleh hasil $\mathrm{H}_{o}$ ditolak dan $\mathrm{H}_{1}$ diterima.

Pada dasarnya proses resolusi konflik ini dilakukan pada saat peserta outbound (kelompok eksperimen) melakukan refleksi setelah sesi outbound diberikan kemudian setelah mereka merefleksi diri trainer memberikan debrifing atau evaluasi secara keseluruhan. Debrifing yang dilakukan trainer inilah yang memperkuat terbentuknya resolusi konflik interpersonal. Akan tetapi didalam Debrifing trainer diharap-kan untuk mendo-rong peserta outbound menemukan insight yang terbaik bagi diri mereka sendiri dan dapat menyampaikan apa yang sebaiknya dilakukan oleh mereka dalam menyelesaikan konflik mereka.

Resolusi konflik yang terbentuk dalam diri remaja juga dikarenakan faktor kesempurnaan otak dan proses berpikir yang jauh lebih baik ketika menentukan sebuah keputusan penting dalam hidupnya. Pada tahap ini remaja berada pada tahap operational formal yakni sudah dapat berpikir abstrak dan membuat hipotesis. Remaja sudah mampu memikirkan sesuatu yang akan atau mungkin terjadi. Remaja adalah masa dimana terjadi peningkatan dalam membuat keputusan dalam berbagai isu dalam hidupnya. Kemampuan inilah yang perlu dikuatkan dalam diri remaja. Namun yang terjadi remaja sering tidak menggunakan kemampuannya dengan baik dan justru terperangkap dalam konflik yang semakin merugikan dirinya. Sehingga remaja perlu sebuah keterampilan untuk meningkatkan kemampuan resolusi konflik inter- 
personal. Metode outbound training memberikan pengalaman yang digemari remaja sehingga memberikan pengaruh yang efektif dalam meningkatkan kemampuan resolusi konflik interpersonal remaja.

\section{SIMPULAN}

Dari hasil penelitian dan pembahasan di atas, penelitian ini menyimpulkan bahwa ada perbedaan yang signifikan nilai test rata-rata pada kelompok kontrol maupun eksperimen antara sebelum dan sesudah mengikuti outbound training sebesar 9,635 pada taraf $\alpha=$
$0,05 \%$. Selain itu, outbound training mempunyai pengaruh yang signifikan sebesar 0,954 terhadap peningkatan kemampuan resolusi konflik interpersonal remaja. Outbound training juga efektif dalam meningkatkan kemampuan resolusi konflik interpersonal remaja berdasarkan beda ratarata antara kelompok eksperimen dan kelompok kontrol sebesar 5,069 pada taraf $\alpha=$ $0,05 \%$. Berdasarkan hasil tersebut, diperoleh kesimpulan akhir bahwa metode outbound training efektif untuk meningkatkan kemampuan resolusi konflik interpersonal pada remaja.

\section{DAFTAR PUSTAKA}

Ancok, Djamaludin. (2002). Outbound Management Training. Yogyakarta : UII Press

Anit Somech. (2008). Managing Conflict in School Teams: The Impact of Task and Goal Interdependence on Conflict Management and Team Effectiveness. Journal of Educational Administration Quarterly, 44, 359

Anna B. Kayes, D. Christopher Kayes and David A. Kolb. (2005). Developing Teams Using The Kolb Team Learning Experience. Journal of Simulation and Gaming, 36, 355

Amanuel G. Tekleab, Narda R. Quigley and Paul. E Tesluk. (2009). A Longitudinal Study of Team Conflict, Conflict Management, Cohesion, and Team Effectiveness. Journal of Group and Organizations Management, 34, 170.

Alisjahbana, S. T., (1986). Antropologi Baru. Jakarta : Penerbit PT Dian Rakyat.

Arikunto, S. (2009). Prosedur Penelitian : Suatu Pendekatan Praktek. Jakarta : Rineka Cipta.

Criblin, J. (1982). Leadership Strategies for Organizations Effectiveness. New York: Amacom.

Desmita. (2007). Psikologi Perkembangan.
Bandung: Rosda.

Deutsch, M., \& Peter Coleman. (Eds). (2000). The Handbook of Conflict Resolution. San Francisco: Josey Bass.

Fitrotun. (2006). Evaluasi Outbound Training dalam Mengembangkan Kompetensi Kepemimpinan Pendidikan di Sekretariat Daerah Propinsi Jawa Timur. Tesis, Surabaya: Universitas Negeri Surabaya.

Elisabeth, S.S. (2010). Studi Perbedaan Kemampuan Manajemen Konflik Ditinjau Dari Persepsi Remaja terhadap Pola Komunikasi Orang Tua. Skripsi. Surabaya : Universitas Airlangga.

Esther, H. (2005). Kekerasan di Sekolah dan Upaya Penanggulangannya. Seminar Nasional HUT ABKIN XVII, Desember 2005 di UM Malang.

Halleyda, Nuriah. (2008). Efektifitas Outbound Training dalam Meningkatkan Keterampilan Sosial pada Anak yang Mengalami Penolakan Teman Sebaya. Tesis. Solo: Universitas Muhammadiyah Surakarta.

Hardjana, A.M., (1994). Konflik di Tempat Kerja. Yogyakarta: Kanisius.

Hendricks, W. (1992). Bagaimana Mengelola 
Konflik. Diterjemahkan oleh : Arif Santoso. Jakarta Bumi Aksara.

Johnson, D.W., \& Johnson, F.P. (2000). Joining Together : Group Theory and Group Skill. Sevent Edition. Allyn and Bacon, Inc, Tokyo.

Martini. (2005). Prosedur dan Prinsip-Prinsip Statistika. UNESA Press: Surabaya.

Muryantinah, dkk. (2011). Efektifitas Outward Bound Training untuk Meningkatkan Harga Diri dan Kemampuan Kerjasama. Jurnal Penelitian Dinamika Sosial (Online), 2 (2), (http://www.journal.unair.ac.id/ login/jurnal/filer/J, diakses 1 Maret 2011).

Nurhidayah, Siti. (2007). Pengaruh Pelatihan Keterampilan Manajemen Konflik terhadap Kecerdasan Emosi Remaja dalam Pengambilan Keputusan. Tesis. Yogyakarta : Universitas Gadjah Mada.

Nurwijayanti, Siti. (2003). Manajemen Konflik dalam Persaingan antar Saudara Sekandung. Skripsi. Malang : Universitas Muhammadiyah Malang.

Sciarra, D. T. (2004). School Counceling: Foundations and Contemporary Issues. Canada: Thompson Brooks/cole.
Sujianto, E. Agus. (2009). Aplikasi Statistik. Jakarta : Prestasi Pustaka.

Tosi, H. L, dkk. (1990). Managing Organizational Behavior. (2nd Edition). Massachusetts: AdissoWesley Publishing Company.

Trihendradi. C. (2009). Analisis statistik. Yogyakarta: Andi.

Wahyudi. (2008). Manajemen Konflik dalam Organisasi. Pontianak Timur: Alfabeta.

Walgito, Bimo. (2007). Psikologi Kelompok. Yogyakarta: Andi.

Walter J. Wheatley. (1993). Enhancing The Effectiveness and Excitement of Management Education : A Collection of Experiental Exercises Derived from Childrens Games. Journal of Simulation and Gaming, 30, 181.

Weitzman, E.A., \& Patricia Flynn, W. (2000). Problem Solving and Decision Making in Conflict Resolution. Dalam Morthon Deutsch, (Eds). The Handbook of Conflict Resolution. San Fransisco: Josey Bass.

Winardi. (1990). Asas-asas Manajemen. Bandung: Penerbit Mandar Maju.

Wikipedia. (2011). Data Konflik Remaja. Diakses dari http://id.wikipedia.org/ wiki.Remaja, pada 19 Februari 2011. 